\title{
10. MAGNETIC PROPERTIES, IRON-TITANIUM OXIDES, AND PETROLOGY OF FOUR LEG 115 BASALTS 1
}

\author{
R. B. Hargraves ${ }^{2}$
}

\begin{abstract}
A detailed study of the Fe-Ti oxides in four basalt samples-one from each of the four holes drilled into basement on Ocean Drilling Program Leg 115 (Sites 706, 707, 713, and 715)-has been performed. Ilmenite is present only in samples from Sites 706 and 715. In the sample from Site 715, Ti-magnetite intergrowths are characteristic of subaerial (?) high-temperature oxy-exsolution; Ti-magnetite in the other three samples has experienced pervasive low-temperature oxidation to Ti-maghemite, as evidenced by the double-humped, irreversible, saturation magnetization vs. temperature $\left(\mathrm{J}_{\mathrm{S}} / \mathrm{T}\right)$ curves.

The bulk susceptibility of these samples, which are similar in terms of major element chemistry, varies by a factor of $\sim 20$ and correlates semiquantitatively with the modal abundance of $\mathrm{Fe}-\mathrm{Ti}$ spinel, as determined by image analysis with an electron microprobe. The variation in $\mathrm{Fe}$-Ti oxide abundance correlates with average grain size: fine-grained samples contain less Fe-Ti oxide. This prompts the speculation that the crystallization rate may also influence Fe-Ti oxide abundance.
\end{abstract}

\section{INTRODUCTION}

Considerable data on the magnetic properties of oceanic basalts has resulted from the study of dredged samples and basement cores acquired in various ocean drilling programs. Concurrently, exhaustive studies have been made of the petrochemistry and petrogenesis of the materials. Iron-titanium oxides, the predominant carriers of the magnetic signature, are a ubiquitous phase in these basalts. Their composition, skeletal textures, and susceptibility to low-temperature oxidation are now well documented and provide a sound basis for interpreting the amplitude, as a function of age, of the total-field magnetic anomalies recorded in ocean surveys (Petersen et al., 1979; Bleil and Petersen, 1983).

During Ocean Drilling Program (ODP) Leg 115, on-board measurements were made of the low-field magnetic susceptibility of the basalt cores collected for paleomagnetic study (Vandamme and Courtillot, this volume). Variations in this property (see Fig. 1) proved to be a valuable empirical aid to petrologists in logging the discontinuous core segments recovered.

Susceptibility varied by a factor of $\sim 20$, but this property could not readily be correlated, either (as might be expected) with the apparent abundance and composition of the "opaques" (given the limited facilities aboard), or with the subtle variations determined in the bulk-rock chemical compositions.

An attempt to understand better the petrologic significance of the large susceptibility variations, which are assumed to be related in some way to the abundance of iron-titanium oxides, has been undertaken here.

\section{SAMPLES STUDIED}

I have made a detailed investigation of the Fe-Ti oxides in four basalt samples, one from each of the sites drilled into basement: Sample 115-706C-4R-3, 10-13 cm, Sample 115-707C-25R-

\footnotetext{
${ }^{1}$ Duncan, R. A., Backman, J., Peterson, L. C., et al., 1990. Proc. ODP, Sci. Results, 115: College Station, TX (Ocean Drilling Program).

2 Department of Geological and Geophysical Sciences, Princeton University, Princeton, NJ 08544, U.S.A.
}

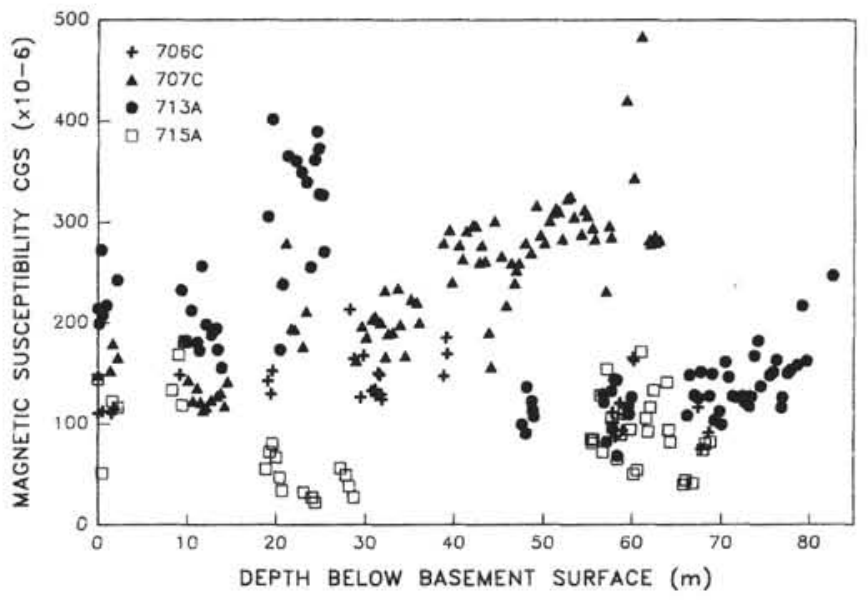

Figure 1. Magnetic susceptibility as a function of depth in the basement core of all minicores drilled for paleomagnetic study (Vandamme and Courtillot, this volume). Symbols for different holes as indicated on figure.

2, 130-132 cm, Sample 115-713A-15R-4, 43-47 cm, and Sample 115-715A-25R-6, 34-37 cm (referred to in this paper by their site numbers only; i.e., $706,707,713$, or 715 ). The samples were selected after a reflected light study of all the polished sections made on board; they represent the full range of susceptibilities measured and microtextures observed. The data acquired, or pertinent to this study, are summarized in Tables 1-4, and the textures are illustrated in Plate 1 . The analytical equipment and/or techniques used are described in the text.

\section{Petrographical Description}

The basalts are typical, fine- to medium-grained (Plate 1), clinopyroxene, plagioclase phyric, with 707 and 715 also containing 3\%-5\% olivine (now completely altered). The 707 sample is most conspicuously microporphyritic. In all, the groundmass, which shows feathery quench textures in reflected light and presumably was never true glass, is now largely altered to brownish opaque clay material (most of the white backgrounds in Plate 1A). 
Table 1. Petrographic properties of basalt samples studied.

\begin{tabular}{|c|c|c|c|c|c|c|}
\hline \multirow{2}{*}{$\begin{array}{l}\text { Core, section, } \\
\text { interval }(\mathrm{cm})\end{array}$} & \multicolumn{4}{|c|}{ Texture and average grain size $(\mu \mathrm{m})$} & \multicolumn{2}{|c|}{ Modal abundance $(\%)$} \\
\hline & Plagioclase & Pyroxene & Ilmenite & Spinel & Oxide $^{a}$ & Magnetite ${ }^{b}$ \\
\hline $115-706 \mathrm{C}-4 \mathrm{R}-3,10-13$ & $\begin{array}{l}\text { Laths, } \\
\quad \leq 400\end{array}$ & $\begin{array}{l}\text { Subophitic, } \\
\text { interstitial, } \\
\leq 100\end{array}$ & $\begin{array}{l}\text { Parallel } \\
\text { growth } \\
\text { laths, } \\
\leq 200\end{array}$ & $\begin{array}{c}\text { Cross arm, } \\
\text { skeletal, } \\
\leq 200\end{array}$ & 4.2 & 2.0 \\
\hline $115-707 C-25 R-2,130-132$ & $\begin{array}{l}\text { Laths, } \\
\qquad \leq 200\end{array}$ & $\begin{array}{l}\text { Laths, } \\
\quad \leq 100\end{array}$ & - & $\begin{array}{l}\text { Cruciform, } \\
\text { skeletal, } \\
10-80\end{array}$ & 2.0 & 2.0 \\
\hline $115-713$ A-15R-4, 43-47 & $\begin{array}{l}\text { Laths, } \\
\quad \leq 400\end{array}$ & $\begin{array}{l}\text { Anhedral, } \\
\text { interstitial, } \\
\leq 300\end{array}$ & - & $\begin{array}{l}\text { Cross arm, } \\
\text { skeletal, } \\
100-200\end{array}$ & 5.2 & 5.2 \\
\hline 115-715A-25R-6, 34-37 & $\begin{array}{l}\text { Stubby } \\
\text { laths, } \\
\leq 200-400\end{array}$ & $\begin{array}{l}\text { Ophitic, } \\
\text { enclosing } \\
\text { plagioclase } \\
\leq 300\end{array}$ & $\begin{array}{l}\text { Laths, } \\
\quad \leq 100\end{array}$ & $\begin{array}{c}\text { Subhedral, } \\
30-50\end{array}$ & 1.0 & 0.5 \\
\hline
\end{tabular}

Note: Ilmenite is not present in samples from Sites 707 and 713.

Measured; see text for technique.

bstimated; ilmenite vs. magnetite abundance could not be resolved quantitatively, and the magnetite contents of samples from Sites 706 and 715 are based on a visual estimate.

Table 2. Magnetic properties of basalts from samples studied.

\begin{tabular}{llrlll}
\hline \multicolumn{1}{c}{$\begin{array}{c}\text { Core, section, } \\
\text { interval }(\mathrm{cm})\end{array}$} & \multicolumn{1}{c}{$x$} & \multicolumn{1}{c}{$\mathrm{J}_{\mathrm{N}}$} & \multicolumn{1}{c}{$\mathrm{J}_{\mathrm{S}}$} & $\mathrm{J}_{\mathrm{h}} / \mathrm{J}_{\mathrm{o}}$ & $\mathrm{T}^{\circ} \mathrm{C}$ \\
\hline $115-706 \mathrm{C}-4 \mathrm{R}-3,10-13$ & 1.5 & 3.1 & 1.3 & 2 & 260 \\
$115-707 \mathrm{C}-25 \mathrm{R}-2,130-132$ & 2.0 & 2.7 & 0.8 & 1.6 & 340 \\
$115-713 \mathrm{~A}-15 \mathrm{R}-4,43-47$ & 3.5 & 11.7 & 0.9 & 1.6 & 305 \\
$115-715 \mathrm{~A}-25 \mathrm{R}-6,34-37$ & 0.25 & 1.1 & 0.3 & 0.5 & 570 \\
\hline
\end{tabular}

Note: $x=$ susceptibility $\times 10^{-4} \mathrm{emu} / \mathrm{cm}^{3} \mathrm{Oe} ; \mathrm{J}_{\mathrm{N}}=$ intensity of natural remanence $\times 10^{-4} \mathrm{emu} / \mathrm{cm}^{3} ; \mathrm{J}_{\mathrm{S}}=$ saturation magnetization, emu/gm; $\mathrm{J}_{\mathrm{h}} / \mathrm{J}_{\mathrm{o}}=$ ratio of saturation magnetization after heating to the original; and $\mathrm{T}^{\circ} \mathrm{C}=$ Curie point.

\section{Bulk Chemistry}

The major and trace element chemistry (determined by X-ray fluorescence analysis on board) of samples adjacent, or closest, to the specific samples studied is listed in Table 3. Although all are generally similar, the largest differences are between the 706 and 715 samples. The former contains over $3 \% \mathrm{TiO}_{2}$, the latter about $1 \%$. The $\mathrm{Fe} / \mathrm{Mg}$ ratio of the 706 sample, with over $15 \%$ " $\mathrm{Fe}_{2} \mathrm{O}_{3}$," is 2.8 , whereas that for the 715 sample (11.8\% " $\mathrm{Fe}_{2} 03$ ") is close to 1 . The FeO values, as determined since by A. N. Baxter, are included to indicate the extreme oxidation of all the samples. The 706 sample has $2.95 \%$ combined alkalis, 715 has $1.84 \%$, and 706 has more conspicuous trace element anomalies.

\section{Iron-Titanium Oxides}

Oxide textures are illustrated in Plates 1B and 1C. Despite the pervasive low-temperature oxidation to titanomaghemite (see magnetic properties), the grains appeared optically homoge-

Table 3. Chemical analyses of the basalt samples studied.

\begin{tabular}{|c|c|c|c|c|c|c|c|c|c|c|c|c|c|}
\hline \multirow{2}{*}{$\begin{array}{l}\text { Core, section } \\
\text { interval }(\mathrm{cm})\end{array}$} & \multirow{2}{*}{$\begin{array}{l}\text { Depth } \\
\text { (mbsf) }\end{array}$} & \multicolumn{10}{|c|}{ Major element } & \multirow[b]{2}{*}{ Total } & \multirow[b]{2}{*}{ LOI } \\
\hline & & $\mathrm{SiO}_{2}$ & $\mathrm{TiO}_{2}$ & $\mathrm{Al}_{2} \mathrm{O}_{3}$ & $\mathrm{Fe}_{2} \mathrm{O}_{3}{ }^{\mathrm{a}}$ & $\mathrm{MnO}$ & $\mathrm{MgO}$ & $\mathrm{CaO}$ & $\mathrm{Na}_{2} \mathrm{O}$ & $\mathrm{K}_{2} \mathrm{O}$ & $\mathrm{P}_{2} \mathrm{O}_{5}$ & & \\
\hline $115-706 C-4 R-3,10-13$ & 66.70 & 48.04 & 3.17 & 13.67 & 15.65 & 0.20 & 5.65 & 10.35 & 2.61 & 0.34 & 0.35 & 100.03 & 0.31 \\
\hline $115-707 C-25 R-1,39-43$ & 404.90 & 49.60 & 1.38 & 14.90 & 13.49 & 0.16 & 7.10 & 11.99 & 2.15 & 0.06 & 0.10 & 100.93 & 0.48 \\
\hline $115-707 C-25 R-3,44-47$ & 407.80 & 49.70 & 1.45 & 15.10 & 13.32 & 0.17 & 7.15 & 11.24 & 2.23 & 0.09 & 0.11 & 100.56 & 0.23 \\
\hline $115-713 \mathrm{~A}-15 \mathrm{R}-4,7-13$ & 131.90 & 49.36 & 1.31 & 14.13 & 13.27 & 0.19 & 8.58 & 11.32 & 2.18 & 0.15 & 0.08 & 100.57 & 0.22 \\
\hline $115-713 \mathrm{~A}-15 \mathrm{R}-41,43-146$ & 132.63 & 49.07 & 1.52 & 13.58 & 14.71 & 0.25 & 5.64 & 12.11 & 2.29 & 0.77 & 0.13 & 100.07 & 1.12 \\
\hline $115-715 \mathrm{~A}-25 \mathrm{R}-6,38-42$ & 237.00 & 47.93 & 0.98 & 14.98 & 11.82 & 0.18 & 10.97 & 11.64 & 1.58 & 0.26 & 0.11 & 100.45 & 0 \\
\hline
\end{tabular}

\begin{tabular}{|c|c|c|c|c|c|c|c|c|c|c|c|c|c|}
\hline \multirow{2}{*}{$\begin{array}{l}\text { Core, section } \\
\text { interval }(\mathrm{cm})\end{array}$} & \multicolumn{13}{|c|}{ Trace elements } \\
\hline & $\mathrm{Rb}$ & $\mathrm{Ba}$ & $\mathrm{Nb}$ & Co & $\mathrm{Sr}$ & $\mathrm{Zr}$ & $\mathrm{Y}$ & $\mathrm{Zn}$ & $\mathrm{Cu}$ & $\mathrm{Ni}$ & $\mathrm{Cr}$ & V & $\mathrm{FeO}^{\mathrm{b}}$ \\
\hline $115-706 C-4 R-3,10-13$ & 3.5 & 139 & 23.0 & 50.0 & 272 & 250 & 43 & 137 & 123 & 48 & 33 & 394 & 0.65 \\
\hline $115-707 C-25 R-1,39-43$ & 1.5 & 30 & 5.3 & 6.9 & 98 & 79 & 34 & 103 & 249 & 69 & 86 & 414 & - \\
\hline $115-707 C-25 R-3,44-47$ & 0.8 & 28 & 6.4 & 7.4 & 99 & 83 & 37 & 112 & 169 & 67 & 88 & 436 & 0.64 \\
\hline $115-713 \mathrm{~A}-15 \mathrm{R}-4,7-13$ & 2.7 & 48 & 4.6 & 7.4 & 92 & 73 & 33 & 84 & 187 & 86 & 222 & 373 & 0.36 \\
\hline $115-713 \mathrm{~A}-15 \mathrm{R}-4,143-146$ & 23.6 & 50 & 7.5 & 9.8 & 96 & 103 & 41 & 111 & 63 & 53 & 135 & 418 & 0.41 \\
\hline $115-715 \mathrm{~A}-25 \mathrm{R}-6,38-42$ & 4.7 & 71 & 8.1 & 6.8 & 105 & 54 & 22 & 78 & 117 & 235 & 483 & 222 & 0.50 \\
\hline
\end{tabular}

Notes: Analyses reported are of samples equivalent, or nearest, to the samples used in this study. Major element values given in wt $\%$ oxide; all trace element values in parts per million $(\mathrm{ppm})$. LOI $=$ loss on ignition.

a Total iron reported as $\mathrm{Fe}_{2} \mathrm{O}_{3}$ is on-board $\mathrm{X}$-ray fluorescence analyses.

b $\mathrm{FeO}$ values determined by A. N. Baxter. 
Table 4. Recalculated electron microprobe analyses of $\mathrm{Fe}-\mathrm{Ti}$ oxides in samples from Leg 115 basalts.

\begin{tabular}{lccccccc}
\hline & & \multicolumn{7}{c}{ Spinels $^{\mathrm{a}}$} \\
\cline { 3 - 8 } Sample & analysis & Usp & Mt & Sp/mf & Her & Hau & Chr \\
\hline 707 & 1 & 0.60 & 0.37 & 0.01 & 0.01 & 0.01 & - \\
707 & 2 & 0.57 & 0.39 & 0.01 & 0.02 & 0.01 & - \\
707 & 3 & 0.58 & 0.39 & 0.01 & 0.01 & 0.01 & - \\
706 & $1 \mathrm{a}$ & 0.52 & 0.37 & 0.08 & - & 0.01 & 0.02 \\
706 & Ib & 0.55 & 0.37 & 0.06 & - & 0.01 & 0.01 \\
706 & $1 \mathrm{c}$ & 0.60 & 0.35 & 0.04 & - & 0.01 & - \\
706 & $1 \mathrm{~d}$ & 0.65 & 0.31 & 0.02 & - & 0.02 & - \\
706 & 2 & 0.58 & 0.35 & 0.05 & - & 0.02 & - \\
706 & 12 & 0.68 & 0.28 & 0.02 & - & 0.02 & - \\
713 & 1 & 0.57 & 0.39 & 0.02 & - & 0.02 & - \\
713 & $9 \mathrm{a}$ & 0.60 & 0.36 & 0.02 & - & 0.02 & - \\
713 & $2 \mathrm{~b}$ & 0.48 & 0.48 & 0.02 & - & 0.02 & - \\
713 & $\mathrm{lb}$ & 0.42 & 0.52 & 0.02 & - & 0.02 & - \\
715 & 1 & 0.14 & 0.84 & 0.01 & - & $<0.01$ & - \\
715 & 2 & 0.08 & 0.90 & 0.01 & - & $<0.01$ & - \\
\hline
\end{tabular}

\begin{tabular}{cccccc}
\hline & \multirow{3}{*}{$\begin{array}{c}\text { Grain } \\
\text { Sample }\end{array}$} & \multicolumn{4}{c}{ Ilmenite $^{\mathrm{b}}$} \\
\cline { 4 - 6 } & analysis & Ilm & Hem & Gei & Py \\
\hline 706 & 9 & 0.86 & 0.11 & 0.02 & 0.01 \\
706 & 10 & 0.84 & 0.11 & 0.04 & 0.01 \\
706 & 11 & 0.88 & 0.07 & 0.04 & 0.01 \\
706 & $\mathrm{~A}$ & 0.86 & 0.10 & 0.03 & 0.01 \\
715 & 1 & 0.91 & - & 0.07 & 0.02 \\
715 & 3 & 0.82 & 0.07 & 0.10 & 0.01 \\
715 & 9 & 0.80 & 0.11 & 0.08 & 0.01 \\
715 & 11 & 0.83 & 0.11 & 0.05 & 0.01 \\
\hline
\end{tabular}

Notes: Electron microprobe analyses were performed on the Rutgers University JEOL Superprobe; $15-\mathrm{kV}$ accelerating voltage, $15-\mathrm{mA}$ current. All elements were measured on W.D.S. crystals, and counts continued until 0.5 standard deviation (SD) was achieved or $40 \mathrm{~s}$ had elapsed. Grains 1a, 1b, 1c, and 1d from Site 706 samples are spot analyses from core to rim of a single zoned grain, as illustrated in Plate 1B, Fig. 1.

a Molecular fractions of Usp = ulvospinel, $\mathrm{Mt}=$ magnetite, $\mathrm{Sp}=$ spinel and $\mathrm{mf}=$ magnesioferrite, Her $=$ hercynite, Hau = hausmannite, and $\mathrm{Chr}=$ chromite.

${ }^{\mathrm{b}}$ Molecular fractions of Ilm = ilmenite, Hem = hematite, Gei = geikielite, and $\mathrm{Py}=$ pyrophanite.

neous. Their compositions, as determined by electron microprobe, are given in Table 4.

Ilmenite is present only in the 706 and 715 samples. In the 706 sample, the ilmenite occurs in remarkable "parallel growth" laths (Plate 1B, Fig. 1), sometimes partly overgrown by magnetite (Plate 1C, Fig. 1). The conventional explanation for such aggregates is that they represent individual skeletal crystals joined in the third dimension (MacKenzie et al., 1982), but no clear evidence of such connections was observed.

In Sample 715, the titaniferous magnetite has undergone pervasive high-temperature oxidation with oxy-exsolution of ilmenite (Plate 1C, Fig. 4). Discrete laths of ilmenite also occur in this sample. The high-temperature oxidation of titaniferous magnetite has come to be interpreted as almost a signature of subaerial eruption (Kono, 1980; Kono et al., 1980). Such a history had independently been inferred for the Site 715 basalts on the basis of their common reddish alteration and their intercalation with sediment.

Of the four samples studied, skeletal textured spinels are found only in the three submarine flows $(706,707$, and 713; Plate $1 \mathrm{~B}$ and Plate 1C, Figs. 1-3). Although comparably fine grained, the spinels in subaerial sample 715 are subhedral (Plate 1C, Fig. 4). The finer grained 707 sample contains the most distinctly cruciform-type spinels, those in the slightly coarser grained 706 and 713 samples being more of the cross-arm type (Haggerty, 1976, p. Hg106).

\section{Modal Abundance}

Quantitative microscopic determination of the modal abundance of such minor, fine-grained opaque phases is essentially impossible. Petersen et al. (1979) compared abundance estimates derived from conventional point counting with results determined by image analysis. They found the former to overestimate the abundance by a factor of 1.5-2.5.

The technique employed here involved image analysis of the variations in gray scale of back-scattered electron images using a JEOL superprobe at Rutgers University (15-kV accelerating voltage, $20-\mathrm{mA}$ current). The "Vista" image analysis program provides the ability to optimize contrast, brightness, and other factors, easing the separation of phases in terms of gray scale and quantitative modal analysis.

Qualitatively, ilmenite could be distinguished from magnetite in the images, but quantitative determination of each has not yet been achieved. A rough estimate of the relative abundance was made when both phases were present, and the total opaque content was subdivided accordingly in Table 1.

\section{Magnetic Properties}

Saturation magnetization $\left(\mathrm{J}_{\mathrm{S}}\right)$ was determined by measurement in fields up to 7500 Oe. The samples were saturated by $\sim 2000$ Oe and, to minimize the paramagnetic contribution, this field was used when measuring (in air) the temperature dependence of magnetization $\left(\mathrm{J}_{\mathrm{S}} / \mathrm{T}\right)$.

As illustrated in Figure 2, the double-humped $\mathrm{J} / \mathrm{T}$ spectral signature of low-temperature oxidation of titaniferous magnetite to titanomaghemite, characteristic of oceanic basalts (Ozima and Ozima, 1971), with a substantial increase in magnetization on cooling, was recorded in the 706,707 , and 713 samples. The sample from Site 715 , in which the titaniferous magnetite had already experienced high-temperature (subaerial?) oxidation, showed a magnetite Curie temperature, with a slight drop in magnetization on cooling. This could be due either to the inversion of original maghemite or to oxidation during the heating cycle.

The susceptibilities (Bartington Model MS.2) characteristic of the samples, intensities of remanence (measured on board), and saturation magnetization are listed in Table 2.

\section{Fe-Ti Oxides and Basalt Crystallization}

The precipitation of an Fe-Ti phase (spinel or rhombohedral) during crystallization of basalt magma appears to depend upon the ferric-ferrous iron ratio and the titanium content. The ferric-ferrous ratio is, in turn, a function of the ambient oxygen fugacity, the temperature of the magma at the time of crystallization, and the alkali content (Carmichael et al., 1974). The $\mathrm{Fe}^{3+}$ is essentially excluded from the main high-temperature silicate phases that crystallize from basalt, and a high activity of this ion promotes early crystallization of magnetite (Osborn, 1957).

Other things being equal, a high $\mathrm{TiO}_{2}$ concentration will be manifest in the early crystallization of ilmenite and in the possible partition of $\mathrm{TiO}_{2}$ into clinopyroxene. In addition to ilmenite, the clinopyroxene of the high- $\mathrm{TiO}_{2}$ sample from Site 706 does indeed show the purplish color of titanaugite.

\section{DISCUSSION}

As would be expected, there is clearly a first-order correlation between the susceptibility and modal abundance of titaniferous magnetite or maghemite in these basalts (cf. Tables 1 and 2 ). In detail, the magnetic susceptibility is further modulated by grain size and texture (fine grain and skeletal texture tending to 

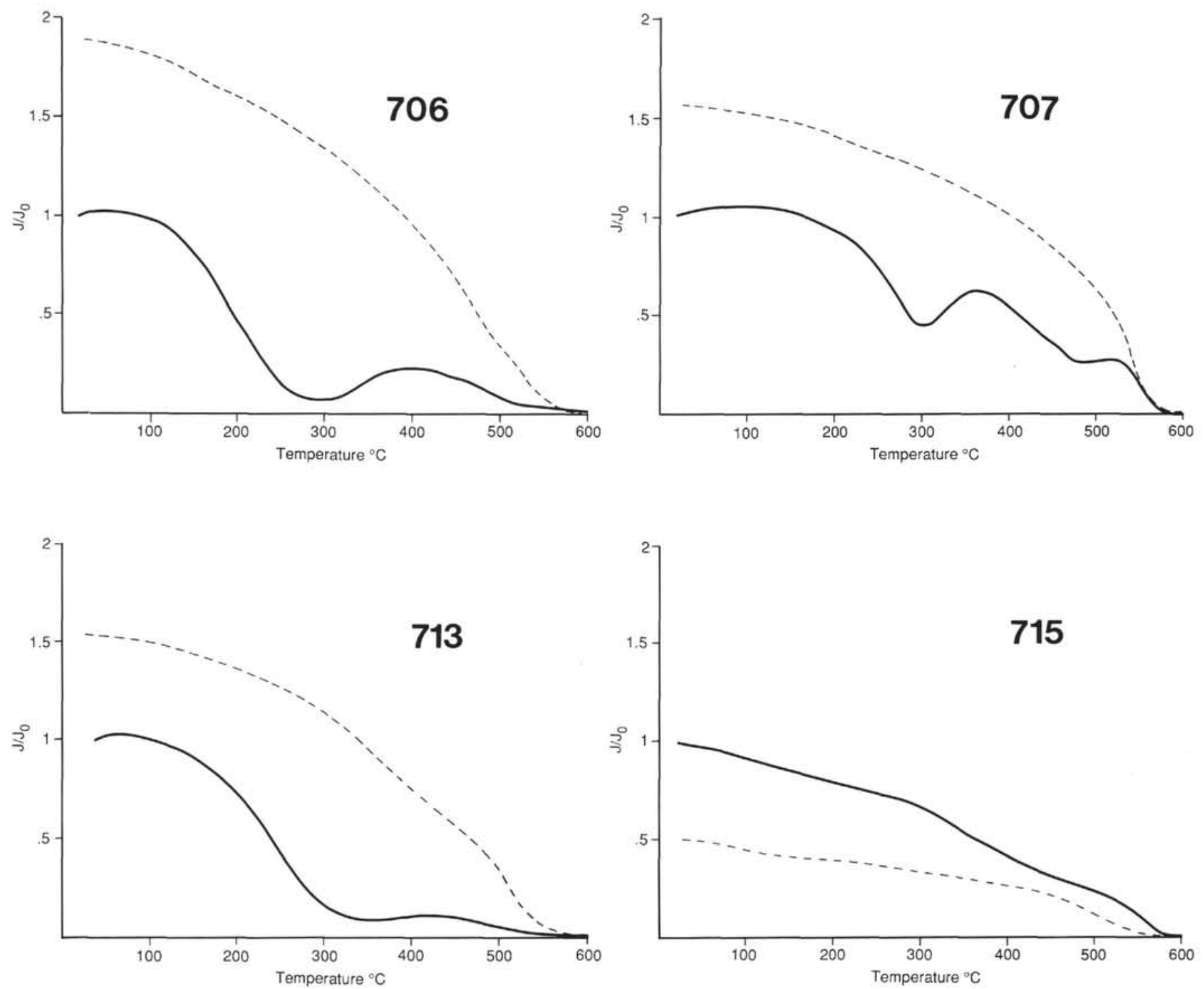

Figure 2. Normalized (to initial intensity, $\mathrm{J}_{\mathrm{i}}$ ) magnetization (J) vs. temperature (T) curves for samples studied: solid, on heating $\left(8^{\circ} \mathrm{C} / \mathrm{min}\right)$; broken, on cooling. Note double-humped heating curves for samples from Sites 706, 707, and 713, which is characteristic of low-temperature oxidation in oceanic basalts (Ozima and Ozima, 1971). The extra hump on the heating curve for the sample from Site 707 is considered to be an artifact of the heating rate employed (Housden et al., 1988).

decrease the initial susceptibility) and the extent of the low-temperature alteration (Stacey and Banerjee, 1974). The latter, inferred from the Curie temperatures, which increase with oxidation, also correlates with increasing age of the basalts, as has been reported.

The influence of grain size and texture of the magnetite grains on the susceptibility is difficult to establish quantitatively. Certainly, in the samples studied here, those with higher susceptibility and modal magnetite are coarser grained in general, and the magnetite grains themselves are larger (cf. the samples from Sites 706 and 713 with those from 707 and 715 in Plate 1).

There is no clear indication in the bulk-rock chemistry (Table 3) as to why the abundance of the Fe-Ti spinel phase should vary as it does. The high $\mathrm{TiO}_{2}$ content of the 706 sample is consistent with the presence of ilmenite, but this phase is also present as discrete grains in the 715 sample, with the lowest $\mathrm{TiO}_{2}$ content.
The ferric-ferrous ratios (see Table 3 ) are very high, but samples have clearly undergone extensive low-temperature alteration and oxidation. The present value of this parameter, therefore, has no relevance to the primary abundance of the $\mathrm{Fe}-\mathrm{Ti}$ oxides.

\section{SUMMARY AND SPECULATION}

There is no obvious clue in these data to the petrologic reason for the variation in $\mathrm{Fe}-\mathrm{Ti}$ oxide abundance. Major element variations appear minor, and the significance of the trace elements is unknown. Intrinsic differences in the magmatic oxygen fugacity could well be the primary cause, but evidence of these has been obscured by the pervasive low-temperature alteration.

An additional factor that may conceivably contribute to the modal variation is the rate of crystallization: That these magmas crystallized rapidly is likely, given that they were extruded. There is (or was) no glass in the samples studied, but the origi- 
nal silicate phases in the cryptocrystalline groundmass-now largely altered to brownish "opaque" clay-may well have served as a sink for components that otherwise would have crystallized as Fe-Ti oxides. There is, however, no apparent variation in the groundmass:crystal proportion commensurate with the variation in oxide mode. Although all lavas cooled rapidly, some of the samples came from the interior of flows, or from thicker units, and presumably crystallized somewhat less rapidly, as evidenced by the variation from fine to medium grain.

The position of spinels (and ilmenites) in the paragenesis of these basalts is not obvious. As they are neither microphenocrysts enclosed by silicate grains nor late-stage products of alteration or devitrification, they appear to have crystallized concurrently with the bulk of the silicate phases.

In general, the grain sizes of the oxides vary directly with that of the whole rock in which they occur. It is this grain-size variation that correlates best with the modal abundance variation and prompts the following speculation. Rapid nucleation and growth of all crystals has occurred. Under such conditions, the major phases (i.e., silicates) may incorporate impurity ions more readily, and ions that, under slower, more ideal crystallization conditions would be partitioned into oxide crystals, may instead tend to be incorporated into silicates, thereby minimizing the eventual oxide mode!

With the advent of a fairly easy technique for determining the oxide mode quantitatively (as described above), a straightforward means of testing the hypothesis is at hand: To measure the modal oxide abundance in samples from an unequivocally single, chemically homogeneous unit that shows a variation from quenched border to medium-grained interior. If the results are positive, this could be followed by experimental studies (e.g., Lofgren, 1980) to constrain further the intensive variables involved.

Should this relationship be confirmed, the results of magnetic susceptibility logging, both downhole and of individual samples on board, may contribute significantly to the determination of the basic stratigraphy of the oceanic crust, which is essential to a better understanding of its origin and evolution. In addition, the demonstration that the kinetics of nucleation and growth may affect significantly the modal abundance of (at least) accessory phases in a closed-system crystallization of magma will be of more general petrologic interest.

\section{ACKNOWLEDGMENTS}

A. N. Baxter made the whole-rock ferrous iron determination, S. Swapp performed the electron microprobe analyses of the oxides, and D. L. Thompson provided the photomicrographs and modal analyses. Their essential contributions are gratefully acknowledged.

\section{REFERENCES}

Bleil, U., and Petersen, N., 1983. Variations in magnetization intensity and low-temperature titanomagnetite oxidation of ocean floor basalts. Nature, 301:384-388.

Carmichael, I.S.E., Turner, F. J., and Verhoogen, J., 1974. Igneous Petrology: New York (McGraw-Hill).

Haggerty, S. E., 1976. Opaque mineral oxides in terrestrial igneous rocks. In Rumble, D., III, Oxide Minerals. Mineral. Soc. Am., Short Course Notes, 3: $\mathrm{Hg} 101-\mathrm{Hg} 300$.

Housden, J., DeSa, A., and O'Reilly, W., 1988. The magnetic balance and its application to studying the magnetic mineralogy of igneous rocks. J. Geomagn. Geoelectr., 40:63-75.

Kono, M., 1980. Magnetic properties of DSDP Leg 55 basalts. In Jackson, E. D., Koizumi, I., et al., Init. Repts. DSDP, 55: Washington (U.S. Govt. Printing Office), 723-752.

Kono, M., Clague, D., and Larson, E. E., 1980. Fe-Ti oxide mineralogy of DSDP Leg 55 basalts. In Jackson, E. D., Koizumi, I., et al., Init. Repts. DSDP, 55: Washington (U.S. Govt. Printing Office), 639652.

Lofgren, G., 1980. Experimental studies on the dynamic crystallization of silicate melts. In Hargraves, R. B. (Ed.), Physics of Magmatic Processes: Princeton, NJ (Princeton Univ. Press).

MacKenzie, W. S., Donaldson, C. H., and Guilford, C., 1982. Atlas of Igneous Rocks and Their Textures: New York (Wiley).

Osborn, E. F., 1957. Role of oxygen pressure in the crystallization and differentiation of basaltic magma. Am. J. Sci., 259:609-647.

Ozima, M., and Ozima, M., 1971. Characteristic thermomagnetic curves in submarine basalts. J. Geophys. Res., 76:2051-2056.

Petersen, N., Eisenach, P., and Bleil, U., 1979. Low-temperature alteration of the magnetic minerals in ocean floor basalts. Am. Geophys. Union, Maurice Ewing Ser., 2:169-209.

Stacey, F., and Banerjee, S. K., 1974. The Physical Principles of Rock Magnetism: Amsterdam (Elsevier).

Date of initial receipt: 1 March 1989

Date of acceptance: 13 November 1989

Ms 115B-127 
A

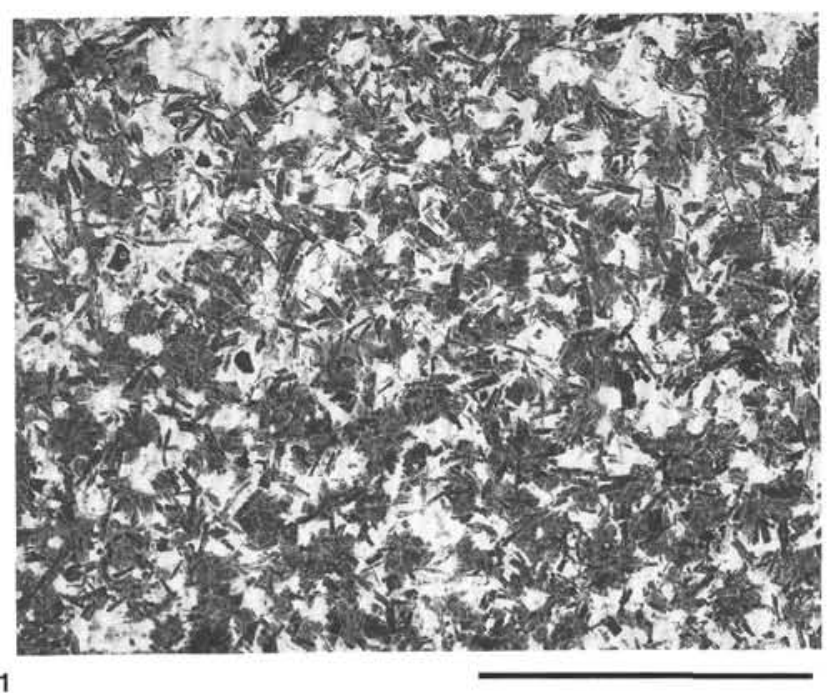

1

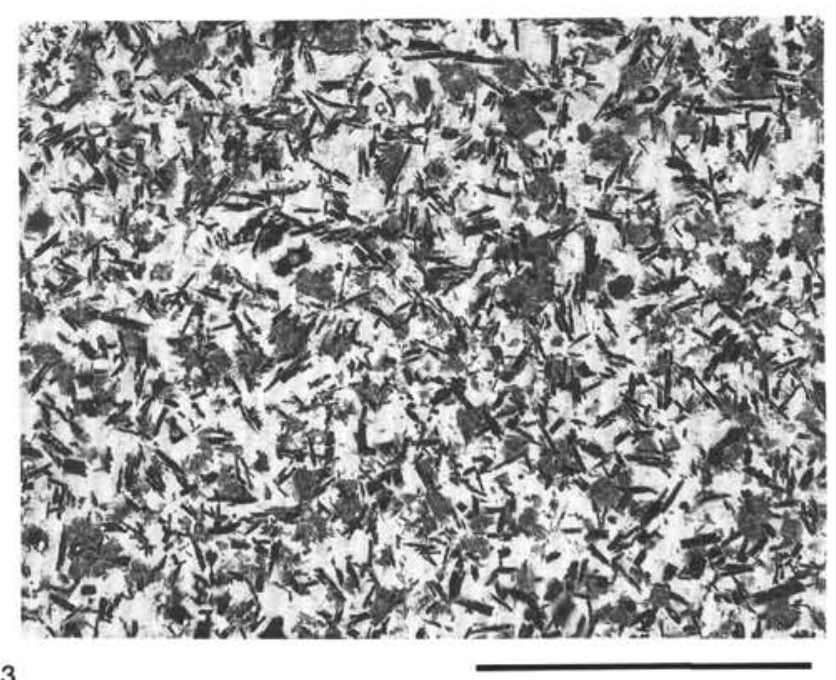

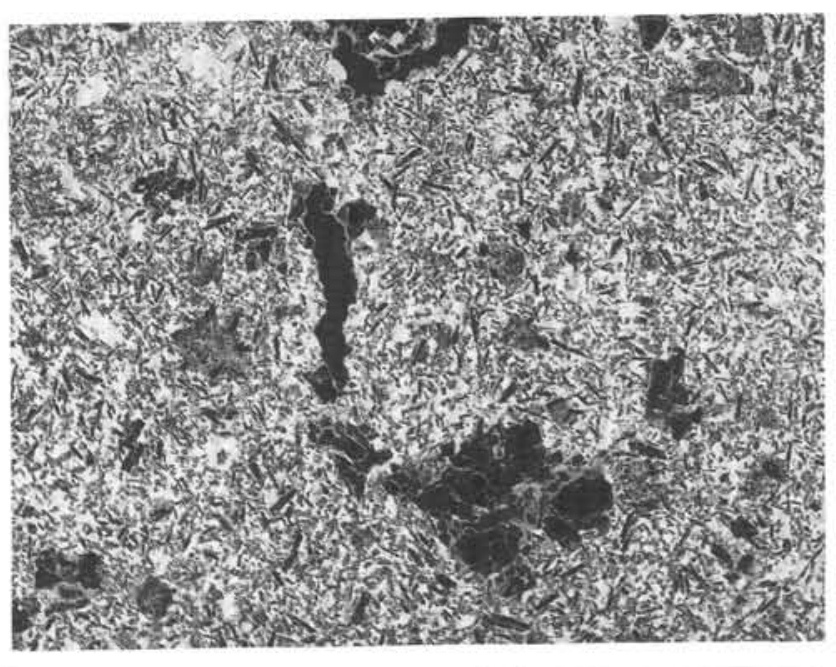

2

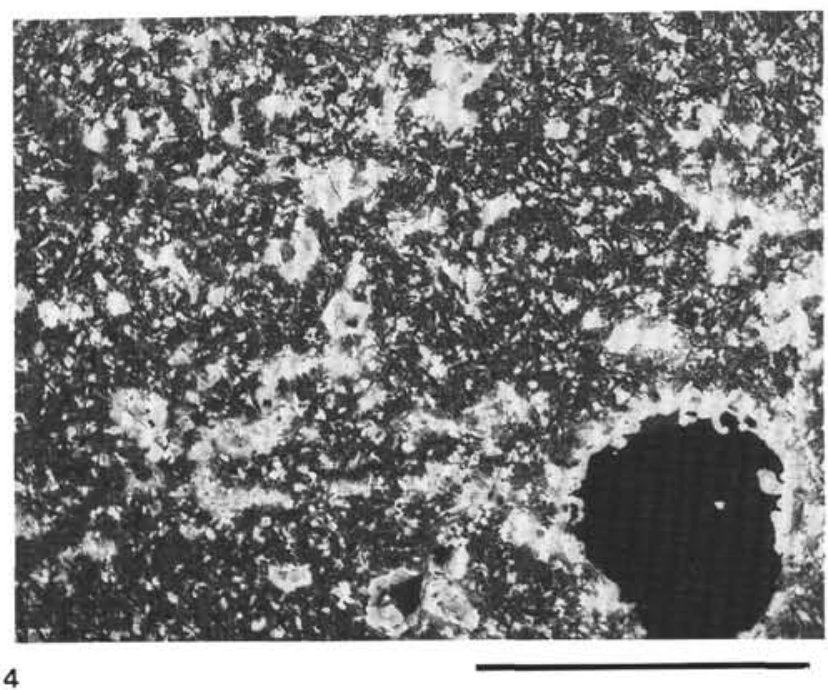

Plate 1. Photomicrographs illustrating variation in texture and grain size of basalt samples studied. Figures numbered 1-4 are of samples from Sites $706,707,713$, and 715 , respectively. Plate $1 \mathrm{~A}$ shows transmitted-light negative images of thin sections (scale bar $=500 \mu \mathrm{m}$ ). Plates $1 \mathrm{~B}$ and $1 \mathrm{C}$ are photographs of electron backscatter images taken on screen of electron probe. Scale bars in Plate 1B are $200 \mu \mathrm{m}$. Scale bar lengths in Plate 1C are indicated on the images. 

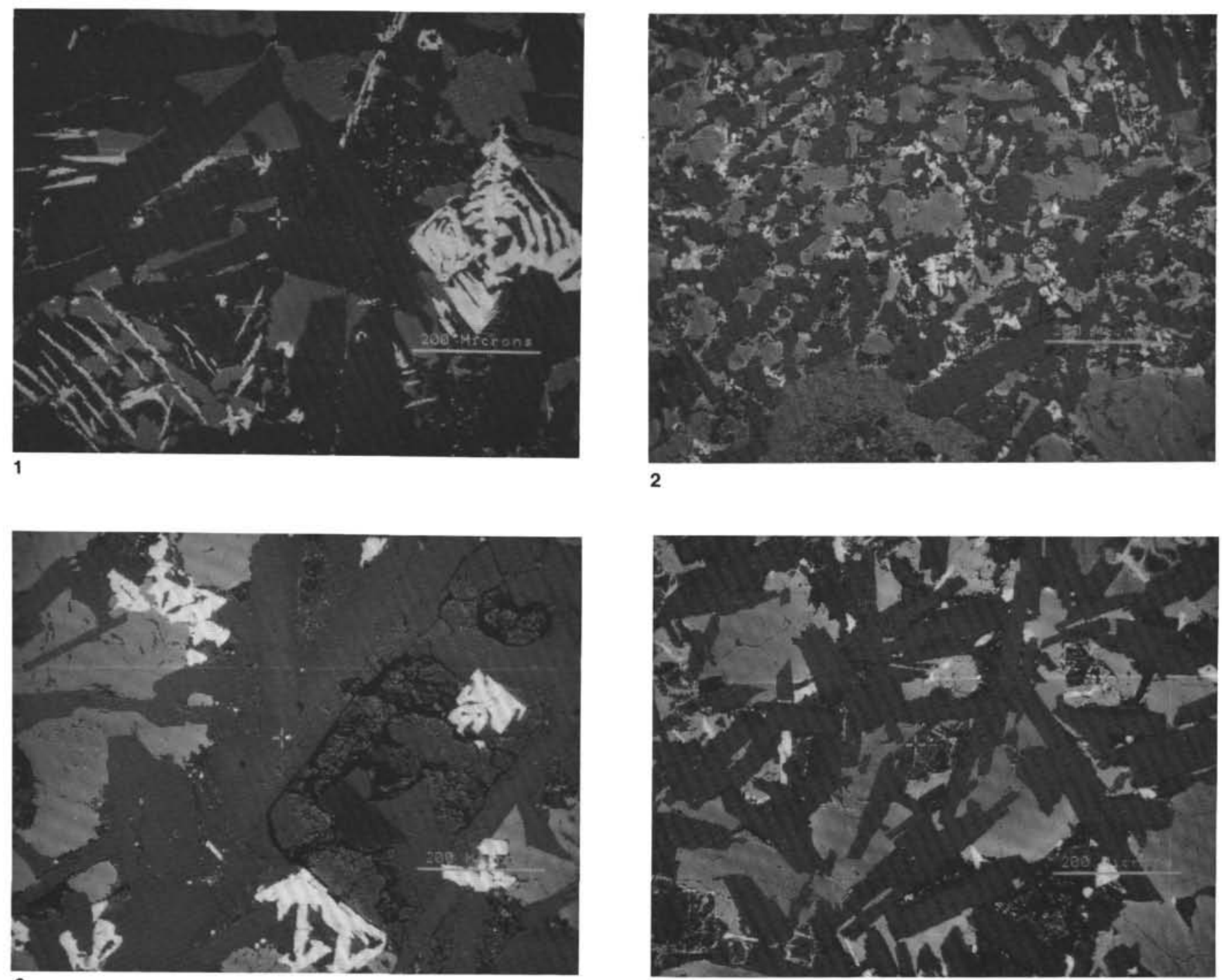

3

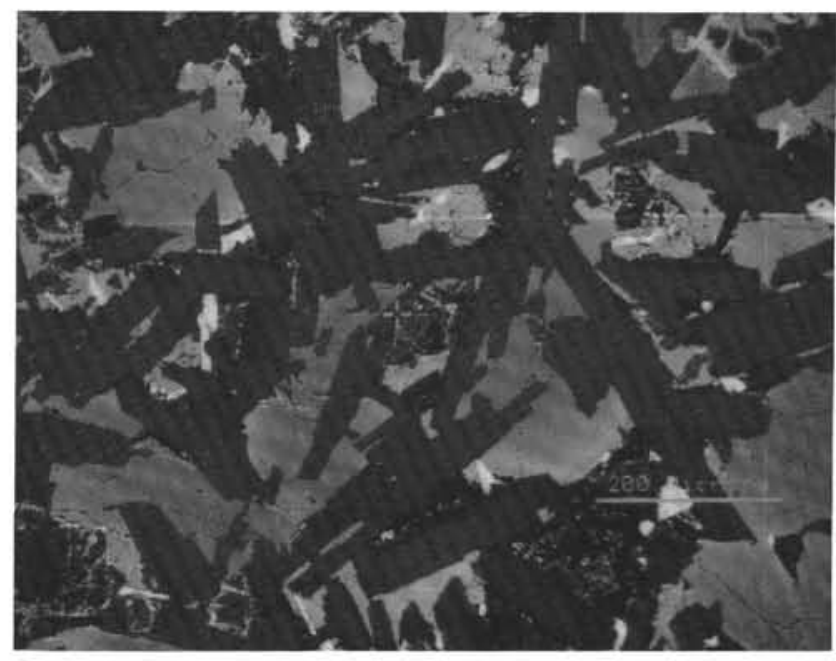

Plate 1 (continued). 

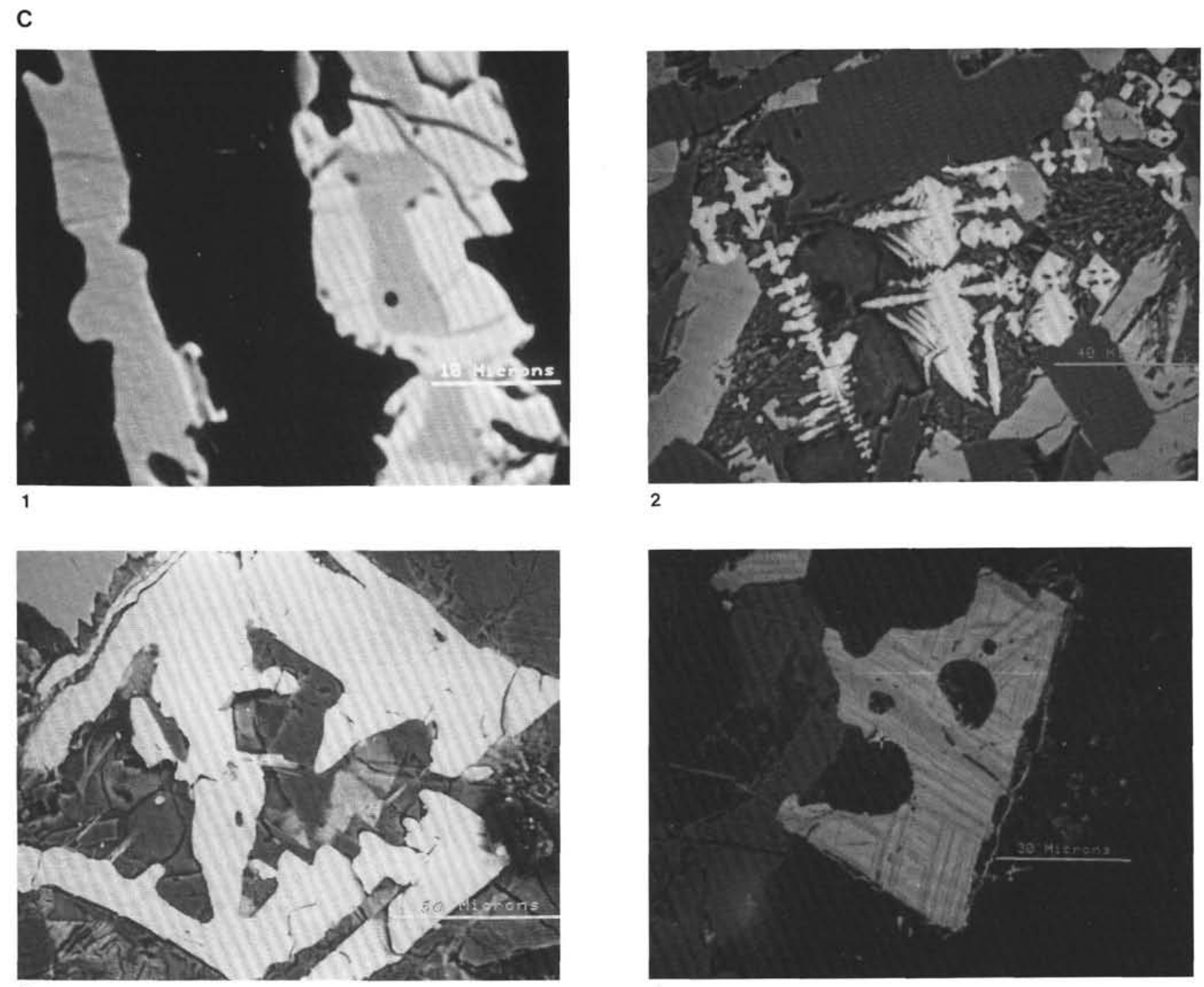

Plate 1 (continued).

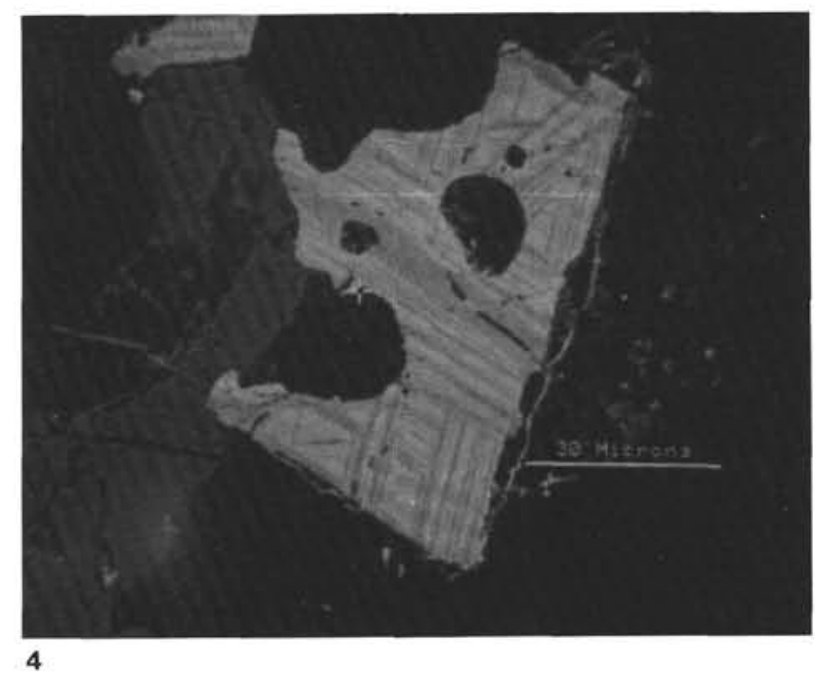

